Harry W. Daniell

\section{Does remifentanil shorten ventilator maintenance, midozolam prolong it, or both alter its duration?}

\author{
Accepted: 13 April 2009 \\ Published online: 17 June 2009 \\ (C) The Author(s) 2009. This article is \\ published with open access at \\ Springerlink.com
}

Dear Sir: Rozendaal et al. [1] should not have concluded that the shortened ventilator weaning time associated with remifentanil use was because of the characteristics of this medication, without considering at least one other possible cause. Cortisol deficiency is present in $30-50 \%$ of patients receiving mechanical ventilation in some series [2,3], and in them has been associated with more than a doubling of weaning time [2] and striking increases in mortality [3]. Acute and prolonged administration of benzodiazepines strongly inhibits cortisol production [4], with a single injection of midazolam at a dose of $0.07 \mathrm{mg} / \mathrm{kg}$ sometimes prominently inhibiting cortisol formation for more than a week [5]. Multiple studies suggest that benzodiazepine-induced lowering of cortisol levels may be enhanced by concurrent use of opioids and propofol, but cortisol levels during the use of remifentanil and propofol have not been investigated. In order to examine the possible effect of medications in each of their study arms on the duration of required mechanical ventilation, any cortisol levels measured in their patients, any administration of corticosteroid therapy to them, relationships between these values and the duration of mechanical ventilation, and withdrawal of patients from the study for any reason, including death, would help to clarify any contributions by remifentanil to the duration of ventilator support and other aspects of patient care.

Open Access This article is distributed under the terms of the Creative Commons Attribution Noncommercial License which permits any noncommercial use, distribution, and reproduction in any medium, provided the original author(s) and source are credited.

\section{References}

1. Rozendaal FW, Spronk PE, Snellen FF, Schoen A, van Zanten ARH, Foudraine NA (2009) Remifentanil-propofol analog-sedation shortens duration of ventilation and length of ICU stay compared to a conventional regimen: a centre randomized, cross-over, openlabel study in the Netherlands. Intensive Care Med 35:291-298
2. Huang CH, Lin HC (2006) Association between adrenal insufficiency and ventilator weaning. Am J Respir Crit Care Med 173:276-280

3. Malerba G, Romano-Girard F, Cravoisy A, Dousset B, Nace L, Levy B, Bollaert PE (2005) Risk factors of relative adrenocortical deficiency in intensive care patients needing mechanical ventilation. Intensive Care Med 31:388392

4. Arvat E, Maccagno B, Ramunni J, DiVito L, Giordano R, Gianotti L, Broglio F, Camanni F, Ghigo E (1999) The inhibitory effect of alprazolam, a benzodiazepine, overrides the stimulatory effect of metyraponeinduced lack of negative cortisol feedback on corticotroph secretion in humans. J Clin Endocrinol Metab 84:2611-2615

5. Kay J, Findling JW, Raff H (1994) Epidural triamcinolone suppresses the pituitary-adrenal axis in human subjects. Anesth Analg 79:501-505

\section{H. W. Daniell (৫)}

Department of Family Practice,

University of California Davis Medical

School, 2626 Edith Avenue, Suite A,

Redding, CA 96001, USA

e-mail: hwdaniell@aol.com 